\title{
ツオンカパの中観思想における言語論的転回について
}

\section{福 田洋一}

\section{1.はじめに}

ツォンカパの中観思想は, 初期の『ラムリム』「毘鉢舎那章」, 中期の『善説心 髄』・『中論注・正理大海』, 後期の『入中論注・密意解明』・『ラムリム小論』の 「毘鉢舎那章」という三期に分けることができる，これらを通じてッォンカパの中 観思想の中心的な主張は, 極めて単純ないくつかの命題に還元することができ， それはこれら三期を通じて余り変化しない。言い換えればツォンカパは生涯を通 じて同じ一つの問題を追及し続けたと言ってもよい.しかし，繰り返し取り組ん だということは，その都度，何らかの点で異なった記述，ひいては異なった主張 をしている可能性を含んでいる，本稿では，中期の代表作『善説心髄』に見られ る言語論的方法に着目して，その議論の基本的枠組みを素描してみたい').

「言語論的転回」とは，リチャード・ローティが 20 世紀の英米系の哲学に顕著 に見られる傾向を指摘して有名になった言葉である ${ }^{2)}$. ローティによれば, 従来の 哲学が主に意識を問題にすることによって哲学的問題に答えようとしたのに対し， フレーゲに始まる現代論理学を背景にして, 哲学的諸問題の解明が, 理想的言語 を再構成すること，あるいは日常的言語の動態を分析することにに還元されると いう方法的意識が今世紀の英米系の哲学を特徵付けているという（The Linguistic Turn, p. 3)。ここで，この用語を援用するのは，もちろんローティが指摘するのと 同じ傾向をツォンカパの思想に見出そうとするためではない. 否定対象の確認と いうツォンカパの中観思想のもっとも重要なテーマを追及するために『善説心髄』 が言語論的方法に訴えていることを示唆するためである.

\section{2. rang gi mtshan nyid kyis grub pa の確認手続き}

『善説心髄』の帰謬派の記述は, rang gi mtshan nyid kyis grub pa なものを言設に おいても認めないことが帰翏派の独自性であることを指摘することから始まる。 
次いで，「それでは，どのようなものとして捉えたならば rang gi mtshan nyid kyis grub paであると捉えていることになるのか」という問いを導入にして一つの科段 を当てて言語論的な視点から rang gi mtshan nyid kyis grub pa の意味を規定しようと している。㷌謬派は rang gi mtshan nyid kyis grub pa 認めないが, ツオンカパの診 断によれば，中観自立派を含め，唯識，経量部，有部など（これらを総称して実在 論と略称する.）はそれを認めている。

gang zag 'dis las 'di byas so // 'bras bu 'di myong ngo zhes pa'i tha snyad btags pa la rang gi phung po 'di nyid gang zag yin nam 'on te de dag las don gzhan zhes gang zag gi tha snyad btags pa de'i don btsal te / don gcig pa'am don tha dad la sogs pa'i phyogs gang rung zhig rnyed nas gang zag de 'jog sa byung na las gsog pa po la sogs par'jog nus la / ma rnyed na 'jog mi nus pas gang zag gi tha snyad btags pa tsam gyis mi tshim par de'i tha snyad gang la btags pa'i btags gzhi de ji ltar yin dpyad cing btsal nas 'jog na gang zag rang gi mtshan nyid kyis grub par 'jog pa yin te / (Legs bshad snying po, Zhol 版, 以下 LN と略称, 65a4-bl)

〔実在論者は〕「この人がこの行為をし，この結果を享受する」という〔日常的言明にお いて「人」という〕名称が〔〈人〉という対象に対して〕使用されたとき，その〔その構 成要素たる〕蘊自身が〈人〉であるのか, それともそれら〔諸蘊〕とは別の物 (don gzhan) が〔〈人〉〕であるのか,〔というように〕「人」という名称が〔それに対して〕使用された ところのもの〔に対応する〕実物（don）を探し求め，それぞれの立場に応じて〔蘊と〕 同一の物であれ, 別の物であれ，なんらか〔の物〕が得られてから，その人を述定する基 体が出てきたならば，〔その〈人〉こそが〕行為〔の潜勢力〕を蓄積する〔主体〕である 等々と述定することができるが，〔人」という名称がそれに対して使用されたところのも のに対応する基体が〕得られないならば,〔〈人〉が行為を蓄積するなどと〕述定すること ができない〔と考える]。それゆえ，「人」という名称が使用されただけで満足せずに，そ の名称が〔それに対して〕使用されたところのもの〔に対する〕基体がどのようなもので あるかを考察し, 探し求めてから〔その名称の対象が存在していると〕述定するならば, 〈人〉が rang gi mtshan nyid kyis grub paであると述定している〔ことになる〕のである. この冒頭の部分にツォンカパの見解は完全に表現されている。ここで議論される 事態を構成する要素は（1）tha snyad, (2) tha snyad btags pa,（3） tha snyad btags pa de'i don に分けられる.（1）はツォンカパが示している例から考えて言語表現な いしは端的に名称と考えてよい（2）は名称が適用された対象である．名称の適 用とは，これもツォンカパの議論内容からすれば，最初に名称を付けるという命 名行為のことではなく，個々の言表行為, すなわち語を使用することと考えられ る. tha snyad btags pa は，その名称がそれに対して適用されたところの対象，すな 
わちその名称によって語られているもののことである。（3）は，そのような名称 の適用対象に対応する実物（don）あるいは基体（gzhi）であり，言語外の根拠を 意味している，ここに挙げられている例では，(1) の名称というのは「この人が この行為をした」という言表における「人」という語である。その名称が適用さ れたものとは「人」という語が指している具体的な, 因果関係の担い手としての 〈人〉のことである，それに対応する実物とは，五繿と同一であるか別異であるか はともかく，その名称の使用の基体となる実在である.

このうち，問われるのは（3）の名指されたものの実物である，その基体があっ て初めて名指されたものの存在が根拠付けられ因果関係を担えることが保証され る，と実在論者は考える。そのとき，その実在論者は名指された対象が rang gi mtshan nyidによって成立していると考えていることになる。ここでツォンカパが 提起しているのは， ある人が，対象が rang gi mtshan nyidによって成立していると 考えていることを検証する手段である。この検証方法は『善説心髄』の中で何度 か言及されるが,「名称の実物ないしは基体がどのようなものかを探求する，ある いは考察する」という実在論者の問いの形式は一定している. 問い求められるも のは, tha snyad pa'i don, (tha snyad btags pa'i) btags gzhi, (tha snyad 'jug pa'i) 'jug gzhi, (tha snyad btags pa'i) btags sa, ming btags pa'i gdags gzhi と用語に若干のバリエーショ ンはあるが, 念頭に置かれている構造はほぼ同じである，ただし上に指摘した三 項が明確に表現されているわけではなく（そのように会通することもできないわけで はないが), 言設とそれが仮設される基体, あるいは言説とそれが指している実物, という言設と基体・実物という二項関係として言及されている.しかし，ここで の問いが言設とその基体という二項関係であったとしても, 以下の引用で検討す るような三項構造からなる論証式が前提とされていると考えられる.

\section{3. 実在論者の立場を表わす論証式}

tshad mas grub par'dod pa thams cad yod par 'jog pa na rang rang gi ming gi tha snyad 'jug pa'i 'jug gzhi'i don de ji 'dra zhig tu grub pa btsal ba na / des rnyed pa'i don med na yod par 'jog mi nus pas de las bzlog pa la yod par'jog go// (LN, 65b2-b3)

〈量によって成立していると認められる全てのもの〉を存在していると述定しようとして, それぞれの名称の言表が志向する（'jug pa）〔先の〕志向基体（'jug gzhi）の実物がどのよ うなものとして成立しているかを探し求めたとき，それによって得られる実物がないなら ば，存在していると述定することはできないので，それとは逆のもの（実物が得られたも 
（188）ツォンカパの中観思想における言語論的転回について（福 田）

の）について, 存在していると述定するのである.

ここでは〈量によって成立していると主張される全てのもの〉を主題として，そ れが実在論者の観点で存在していると述定できるための条件を求めている。その 条件は, それぞれの主題となっているものの言語表現が志向する対象である実物 が存在することである。〈量によって成立していると主張される全てのもの〉に は, 上の例で言及された〈人〉も含まれるので, 以下〈人〉を例に考えていきた い. tha snyad 'jug pa'i 'jug gzhi'i don という表現では, tha snyad 'jug pa も'jug gzhi も donも同じものを指していると考えられる.すなわち，「人」という名称・概念が 志向しているものが志向の基体であり，それは同時に実在上の存在である.ここ では，言設とその仮設の基体という二項関係が前提となっているが，それは論証 因で述べられている関係であり，論証式全体の主題として〈人〉という対象が別 に確保されている.「人」という言語表現は, 主題である〈人〉を指す名称として 使用される。その言語表現が言語外の実物を志向基体 ('jug gzhi) としている場合, それによって語られる〈人〉という対象の存在が確認される。以上の分析から， 〈人〉という主題を中心として, それを表現する「人」という言語表現とその志向 基体としての実物という三項関係が認められる.

実在論者が, その主題についての言語表現の志向基体を確認することで, その 主題となっているものの存在を措定できると考えるとき, その実在論者は対象が 単に存在していると述定できるだけではなく，自らの（rang gi）mtshan nyidによっ て成立している (grub pa) と考えていることになる，とツオンカパは診断する。と するならば，ある対象が自らの mtshan nyidによって成立していることとは，自ら を述べる名称 (rang gi ming gi tha snyad) が志向基体としての何らかの実物を拠り所 としていることであると言えるであろう。一方, 㷌謬派の立場では, そのような 名称の志向基体たる実物は, 探しても見出せないので, 存在しない. 従って, 言 語表現はその対象に対して使用されるだけであり, そのように名指された対象は, 語によって指し示されただけで十分にその効用を果たす。〈人〉について〈存在し ている〉と述定することも有意味に行われる。このとき, この〈人〉という存在 は, 名称が使用されただけのもの, 名指されただけの存在 (tha snyad btags pa tsam) である。

4. mtshan mtshon gzhi gsum との関係

以上のようなツォンカパの rang gi mtshan nyid kyis grub pa の理解は, チベット論 
理学に独特の mtshan nyid, mtshon bya, mtshan gzhi の三つ組みの構造 ${ }^{3)}$ と密接な 関連を持っているように思われる，チベット論理学の用語法では, mtshan gzhi が 主語, mtshon bya がそれに対する述語, mtshan nyid は, その mtshan gzhi を mtshon bya であると述定するための根拠となって一種の論証式を構成する．また mtshon bya は tha snyad と言い換えることもできる（tha snyad mtshon bya と言い換えること ができないとしても). mtshon bya ないしは tha snyad の述定根拠が mtshan nyid であ る. mtshan nyid は, mtshon bya の rgyu mtshan（根拠）であり, don gyi chos（実在 上の意味対象) であり, tha snyad の don $\operatorname{ldog}$ (実在上の意味対象) とも言い換えられ， 名称・概念としての tha snyad の実在の側での述定根拠を意味している. ツォンカ パの言う, 名称の志向する先の基体としての実物 (tha snyad'jug pa'i'jug gzhi'i don) が, ここで言う mtshan nyid と同じ性格のものであることは明らかであろう.

次の文章も, mtshan mtshon gzhi と密接に関連することが見て取れる例である. sa dang sra ba sogs mtshan mtshon du 'jog pa la yang mtshan mtshon gyi tha snyad 'jug pa'i 'jug gzhi de sngar ltar btsal nas rnyed pa'i don la 'jog na de gnyis 'jog mi nus kyang phan tshun ltos pa'i sgo nas de dag yod par'jog go // (LN, 67a3-a4)

たとえば，地と〔その定義的特質である〕堅さを，〔それぞれ〕 mtshan nyid と mtshon bya であると述定する場合にも，前〔の例と同じ〕ょうに探し求めて得られた実物を指して 〔，それが〕「mtshan nyid」と「mtshon bya」という名称が志向する基体であると設定する と[主張〕するならば, 〔そのような実物は得られないので, 〕その二つを〔それぞれ mtshan nyid, mtshon bya であると〕述定することができないが, 〔我々帰謬派の立場では〕相互 関係を通じてそれらが〔mtshan nyid, mtshon bya として〕存在していると述定する〔こと ができる]。

この文ではたまたま mtshan nyid, mtshon bya に言及しているが，これらは前述の mtshan nyid と tha snyad の関係とは別のものである。ここで言及される mtshan nyid と mtshon bya はそれ自体としては mtshon bya ないしは tha snyad に他ならず，問わ れているのは，「地〉は mtshon bya である。〈堅さ〉はその mtshan nyid である.」 と述定できる根拠である。これは mtshan mtshon gzhi を述べる論証式で言えば, 述 定の根拠としての mtshan nyid を問うているのに他ならない. 㷌謬派はこのような 実物を認めないので，そのような実物を mtshan nyid として mtshon bya を述定する ことも承認しないが, もちろん mtshan nyid, mtshon bya の関係は認めている. 地 を mtshon bya, 堅さを mtshan nyid とすること自体は承認してているからである.

それでは，実在論と帰謬派の本質的な相違はどこにあるのであろうか。この問 
題を, 具体例を通して説明する紙数は残されていないので, 結論のみを簡単に述 べるならば，実在論が言設の述定根拠を言語外の実在に求めるのに対し，㷌翏派 は言設の述定根拠が言語外にあることを否定し，言語が有意味に使用されている こと以上の分析を拒否することにある。言設の述定根拠が否定されるので，言設 は単に述べられただけで有意味に機能する。実在論者は, 言語の総体の外に言設 の述定根拠がなければ，その言設が有意義に機能しないと考える. 以上のことを ツォンカパは『プラサンナパダー』から,「トルソーの胴体」と「ラーフの頭」と いう表現を巡る論理学者とチャンドラキールティの問答を引用し, しかも面白い ことにチャンドラキールティの意図とは全く異なった文脈で説明している. 有意 味な言語使用という基準を導入して帰謬派の立場を説明するツオンカパの議論は まさに言語論的傾向をはっきり示していると思われるが, その分析は別の機会に 譲らなければならない.

1）「転回」というからには，それ以前の著作との比較が必要となるが, 紙数の関係もあ り本稿では『善説心髄』のいくつかの表現を分析するに止めなければならない.

2）ローティが今世紀の英米哲学のエポックメイキングな論文を編集したアンソロジーに The Linguistic turn というタイトルを付け, その序論の中で, その方法論的な傾向を総括 している. The Linugistic Turn: Recent essays in philosophical method, edited by Richard M. Rorty, The University of Chicago Press (1967).

3）拙稿「初期チベット論理学における mtshan mtshon gzhi gsumをめぐる議論について」 『日本西蔵学会々報』第 49 号, 2003 年, pp. 13-25を参照.

〈キーワード〉 ツォンカパ, 中観, 言語論的転回, チベット論理学

(大谷大学助教授) 